\title{
Holoprosencephaly Type 4
}

National Cancer Institute

\section{Source}

National Cancer Institute. Holoprosencephaly Type 4. NCI Thesaurus. Code C75475.

A rare disorder caused by mutations in the TGIF gene mapped to chromosome 18p11.3.

It is characterized by semilobar holoprosencephaly, hypotelorism, and ptosis. 